\title{
THE ROLE OF NATURAL BIOPOLYMERS IN GENOTOXICITY OF MUTAGENS/ CARCINOGENS ELIMINATION
}

\author{
Eva Miadokováa, Soňa Svidováa , Viera Vlčkováa, Viola Dúhováa, Eva Pražmáriováa, \\ Katarína Tothováa, Slavomíra Nad’ováa ${ }^{\text {a Grigorij Kogan }}$, Peter Rauko ${ }^{\mathrm{c}}$ \\ a Department of Genetics, Faculty of Sciences, Comenius University, Mlynská dolina, B-l, 84215 Bratislava, Slovak \\ Republic \\ ${ }^{b}$ Institute of Chemistry, Slovak Academy of Sciences, Dúbravská cesta 9, 84238 Bratislava, Slovak Republic, \\ c Institute of Experimental Oncology, Slovak Academy of Sciences, Vlárska 7, 83391 Bratislava, Slovak Republic \\ e-mail:miadokova@fns.uniba.sk
}

Received: June 10, 2005; Accepted: September 25, 2005

Key words: Antigenotoxicity/Carboxymethyl glucan/Biological response modifiers/Cancer prevention and therapy/Natural biopolymer

Nowadays naturally occuring compounds with the potential antimutagenic and anticarcinogenic effects are of great importance for their prospective use in cancer chemoprevention and treatment. The new water soluble derivative of microbial polysaccharide $\beta$-D-glucan-carboxymethyl glucan (CMG) belongs to such a category of natural substances. CMG isolated from the cell wall of baker's yeast Saccharomyces cerevisiae is included into the class of biopolymers known as biological response modifiers (BRMs) with a broad range of activities, above all ones interfering with cancer therapy. It was demonstrated on four experimental model systems that biological and consequential medicinal importance of CMG is based on the combined application with another active compound. In the Saccharomyces cerevisiae antimutagenicity assay CMG significantly reduced ofloxacin-induced mutagenicity in the yeast strain D7. CMG exerted bioprotective (anti-toxic and antimutagenic) effect after its simultaneos application with methyl methanesulphonate on the repair-deficient strain uvs 10 of the unicellular green alga Chlamydomonas reinhardtii. In the Vicia sativa simultaneous phytotoxicity and anticlastogenicity assay CMG exerted statistically significant anticlastogenic efect against maleic hydrazide-induced clastogenicity in Vicia sativa L. Only in the Salmonella/microsome assay CMG did not exert statistically significant antigenotoxic effect, despite of the fact that it reduced 9-aminoacridine-induced mutagenicity in S. typhimurium TA97, but his ${ }^{+}$revertants decreasing was statistically significant only at the highest CMG concentration used. The data presented unambiguously documented that even biopolysaccharides (e.g., derivatives of $\beta$-glucan) belonging to the most abundant class of natural biopolymers may contribute to cancer prevention and therapy.

\section{INTRODUCTION}

A rational use of chemopreventive agents is based not only on the assessment of their efficacy and safety but also on understanding of their mechanisms of action. A detailed classification is proposed which covers variety of mechanisms interfering with different phases of mutagenesis and carcinogenesis. Several mechanisms, such as inhibition of genotoxic effects, antioxidant activity and scavenging of free radicals, inhibition of cell proliferation and signal transduction modulation can be involved ${ }^{1-3}$. To such compounds also belong microbial skeletal polysaccharides which possess marked immunological properties ranging from non-specific stimulation of host immune system, resulting in antitumor, antiviral and anti-infective effects, to antioxidant, antimutagenic or hematopoetic activity ${ }^{4-7}$. In the recent years much evidence has been collected indicating that microbial polysaccharides play a role of signalling molecules for innate immune system ${ }^{8}$ where they are recognized by genetically predetermined pattern recognition receptors (PRRs) located on the surface of immunocompetent and also other type of cells (e.g., epitelial ${ }^{9-11}$. Among the yeast polysaccharides, specific PRRs have been idenfied and described for $(1 \rightarrow 3)$ $\beta$-D-glucans ${ }^{9,12}$.

$\beta$-Glucans isolated from fungi, bacteria and lichens belong to the class of substances known as biological response modifiers (BRMs), which modify the host's biological response by stimulation of the immune system ${ }^{13}$.

Recet decades have brought increased attention to the research of BRMs. Introduction of regulatory peptides and biomodulators in combination with chemotherapy (biotherapy) was a significant contribution to antineoplastic therapy. Among the microbial polysaccharides mainly derivatives of $\beta$-glucans isolated from the cell walls of yeast and fungi have been studied regarding their anticancer activities. The efficiency of chemotherapy of Lewis lung carcinoma with cyclophosphamide was affected by administration of the yeast carboxymethyl glucan - a well-known macrophage simulator ${ }^{14}$. Soluble $\beta$-glucan enhanced killing of retinal carcinoma micrometastases ${ }^{15}$. 
As some polysaccharides isolated from the yeast cell walls belong to the class of substances known as BRMs with a broad range of activity, and the principal strategy of new anticancer drug modulators evaluation involves also antimutagenicity/anticarcinogenicity studies, the main concern of the present study has been given to examination of the carboxymethyl glucan (CMG) eligibility to exert antigenotoxic effect after its application on four genetic model organisms.

\section{MATERIAL AND METHODS}

Material: Carboxymethyl glucan (CMG) is a derivative of $\beta$-D-glucan which was isolated from the cell walls of baker's yeast $S$. cerevisiae by extraction with diluted alkali $\left(6 \% \mathrm{NaOH}\right.$ at $60{ }^{\circ} \mathrm{C}$ ) followed by treatment with diluted acid (4\% phosporic acid extraction at room temperature) ${ }^{16}$. Insoluble $\beta$-D-glucan was solubilized by carboxymethylation described in detail by Machová et al. ${ }^{16}$. The degree of substitution (DS) determined by potentiometric titration was 0.8 and molecular weight determined by HPCL was $250 \mathrm{kD}$.

Mutagens/carcinogens: 9-Aminoacridine (9-AA) (Serva); Methyl methanesulfonate (MMS) (Aldrich); Maleic hydrazide (Serva) and Ofloxacin (Hoechst-Biotika) were of the highest purity available.

Saccharomyces cerevisiae toxicity and antimutagenicity assay: As a testing procedure the assay according to Zimmermann ${ }^{17}$ was used. Prior to each experiment the D7 strain (MATa/MAT , ade2-40/ade2-119, trp5-12/trp5-27, ilv1-92/ilv1-92) was tested for the frequency of spontaneous revertants at the isoleucine locus (ilv1). Exponentially growing cells were treated with ofloxacin $(600 \mu \mathrm{g} / \mathrm{ml})$ and CMG $\left(1 \times 10^{-6} \mathrm{M} ; 1 \times 10^{-5} \mathrm{M}\right)$ for $22 \mathrm{~h}$ at $28^{\circ} \mathrm{C}$. After the treatment, washed cell suspensions $\left(1-2 \times 10^{6}\right.$ cells/plate $)$ were plated on selective medium without ilv, and $2 \times 10^{2}$ to $2 \times 10^{3}$ cells/plate on a synthetic medium to detect survival. The plates were incubated at $28{ }^{\circ} \mathrm{C}$ for $5-12$ days.
Results are means of five experiments. For statistic analysis Student's t-test was used.

Chlamydomonas reinhardtii bioprotectivity assay: Algal (recombination-repair-deficient) strain $u v s 10$ of the unicellular green alga Chlamydomonas reinhardtii, isolated at the Department of Genetics, Faculty of Science, Comenius University, Bratislava, Slovakia ${ }^{18}$ was treated with MMS (0.1-0.5\%) and simultaneously with MMS and CMG $\left(10^{-6} \mathrm{M}\right)$ for $30 \mathrm{~min}$ in the dark, and then plated on agar dishes ${ }^{19}$. Survival was evaluated by microscopic method which enabled to distinguish algal cells died due to cytotoxic and due to genotoxic (lethal mutations) effect of MMS. Results are means of five experiments. For statistic analysis Wilcoxon's two sample test was used.

Simultaneous phytotoxicity and anticlastogenicity assay: This assay was carried out on plant species Vicia sativa (L.) according to Murín ${ }^{20}$. After $24 \mathrm{~h}$ of soaking at $25^{\circ} \mathrm{C}$ in the tested CMG $\left(10^{-5} \mathrm{M}\right)$ and maleic hydrazide $(\mathrm{MH})$, which was used as a positive control ${ }^{21}$, the seeds of $V$. sativa were allowed to germinate on Petri dishes (diameter $=18.5 \mathrm{~cm}$ ) with filter paper soaked with the same concentrations of tested $\mathrm{CMG}$ and $\mathrm{MH}$ as those used for soaking. Phytotoxicity was assayed after $72 \mathrm{~h}$ of the dark cultivation in the thermostat at $25{ }^{\circ} \mathrm{C}$. The seedlings roots of $V$. sativa were measured, and the growth inhibition percentages were assessed. The seedlings in which the root growth was inhibited at least by $25 \%, 50 \%$ and $75 \%$ were fixed and used for chromosome and genome mutability evaluation. The roots were fixed and permanent slides were prepared by the Feulgen method. Chromosome aberrations were determined at least in 500 ana-telophases. For statistic analysis the Student's t-test was used.

Salmonella/microsome assay (Ames assay): For the potential $\mathrm{CMG}$ antigenotoxicity assessment the Ames assay was performed according to the published procedure by Maron and Ames ${ }^{22}$. The Salmonella typhimurium tester strains TA97, TA98 TA100, TA102 were obtained

Table 1. The anticlastogenic effect of CMG against MH-induced clastogenicity in Vicia sativa L.

\begin{tabular}{|l|l|c|c|c|}
\hline Test agent & \multicolumn{1}{|c|}{ Concentration } & $\begin{array}{c}\text { Number of } \\
\text { cells analysed }\end{array}$ & $\begin{array}{c}\text { Number of } \\
\text { aberrations }\end{array}$ & $\begin{array}{c}\% \text { of } \\
\text { aberrations }\end{array}$ \\
\hline Control & & 1129 & 2 & $0.18 \pm 0.13$ \\
\hline $\mathrm{MH}$ & $1.12 \times 10^{-3} \%$ & 1047 & 253 & $24.16 \pm 1.32$ \\
\hline $\mathrm{MH}+\mathrm{CMG}$ & $1.12 \times 10^{-3} \%+10^{-5} \mathrm{M}$ & 1023 & 137 & $13.39 \pm 1.10 * *$ \\
\hline $\mathrm{MH}$ & $0.56 \times 10^{-3} \%$ & 1021 & 72 & $6.64 \pm 0.79 * *$ \\
\hline $\mathrm{MH}+\mathrm{CMG}$ & $0.56 \times 10^{-3} \%+10^{-5} \mathrm{M}$ & 1084 & 59 & $4.58 \pm 0.58$ \\
\hline $\mathrm{MH}$ & $0.28 \times 10^{-3} \%$ & 1289 & 31 & $2.69 \pm 0.48 * *$ \\
\hline $\mathrm{MH}+\mathrm{CMG}$ & $0.28 \times 10^{-3} \%+10^{-5} \mathrm{M}$ & 1151 & 179 \\
\hline
\end{tabular}

Values are mean $\pm \mathrm{SD}$; Control $=\mathrm{H}_{2} \mathrm{O} ; \mathrm{CMG}=$ carboxymethyl glucan; $\mathrm{MH}=$ maleic hydrazide. ** significant difference between $\mathrm{MH}$ and $\mathrm{MH}+\mathrm{CMG}$ at $\mathrm{p}<0.01$. 


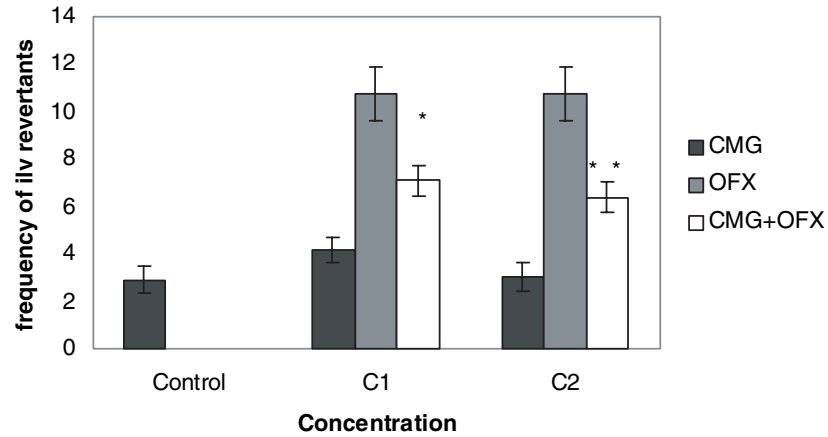

Fig. 1. Antimutagenic effect of CMG against ofloxacininduced ilv- 1 revertants in $S$. cerevisiae D7. CMG = carboxymethyl glucan $\left(\mathrm{C} 1=1 \times 10^{-5} \mathrm{M}, \mathrm{C} 2=\right.$ $\left.1 \times 10^{-6} \mathrm{M}\right)$; OFX = ofloxacin $(600 \mu \mathrm{g} / \mathrm{ml})$; Control $=\mathrm{DMSO}$;

* significant difference between OFX and $\mathrm{OFX}+\mathrm{CMG}$ at $\mathrm{p}<0.05$.

** significant difference between OFX and $\mathrm{OFX}+\mathrm{CMG}$ at $\mathrm{p}<0.01$.

from the Masaryk Univerzity Collection, Brno, Czech Republic. Test tubes containing CMG in three concentrations $(750 \mu \mathrm{g} /$ plate, $500 \mu \mathrm{g} /$ plate, $250 \mu \mathrm{g} /$ plate $)$ either alone or with relevant diagnostic mutagen were placed on minimal bottom agar plates. $\mathrm{His}^{+}$revertants were counted after $72 \mathrm{~h}$ of incubation at $37{ }^{\circ} \mathrm{C}$ on Biotran III Colony Counter (New Brunswick Scientific Co). Results are means of seven experiments. For statistic analysis the Student's t-test was used.

\section{RESULTS}

In this study potential antigenotoxic properties of CMG were investigated using yeast, algae, plant and bacteria as model genetic systems.

CMG significantly reduced the frequency of ofloxacininduced revertants at the ilvl locus in the toxicity and antimutagenicity assay in S. cerevisiae D7 (Fig. 1). It can be suggested that the antimutagenic effect of $\mathrm{CMG}$ against ofloxacin may be based on its ability to scavenge reactive oxygen species.

Results obtained after simultaneous treatment of algal recombination-repair-deficient strain uvs 10 with MMS and CMG documented that CMG exerted bioprotective effect (Fig. 2) because it reduced cytoxicity and mutagenicity (lethal mutations) of MMS.

Data obtained from the simultaneous phytotoxicity and anticlastogenicity assay revealed that $10^{-6} \mathrm{M} \mathrm{CMG}$ significantly reduced clastogenic effect of $\mathrm{MH}$ applied on V. sativa seeds (Table 1).

However, in the Ames assay CMG did not exert statistically significant antimutagenic/anticarcinogenic effect (so that data are not shown), despite of the fact that it reduced 9-aminoacridine-induced mutagenicity in $S$.

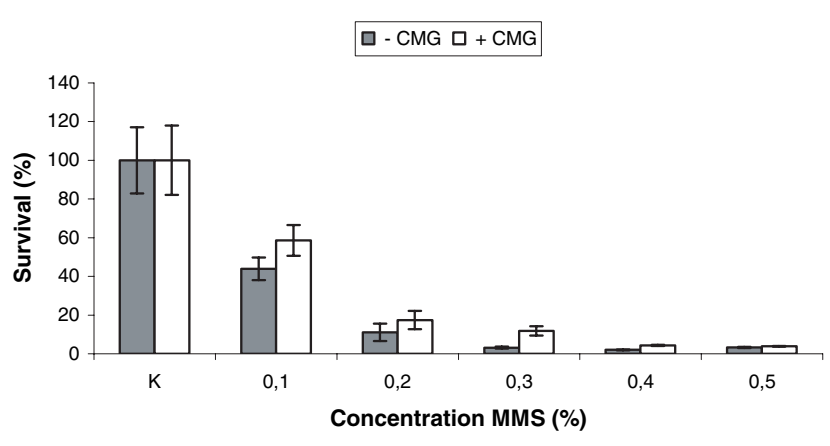

Fig. 2. Bioprotective effect of CMG against MMS-induced cytoxicity and mutagenicity in recombination-repairdeficient strain uvs 10 of Chlamydomonas reinhardtii. $\mathrm{C}=$ control; $\mathrm{MMS}=$ methyl methanesulfonate $(0.1$ $0.5 \%)$

* significant difference between variats with and without $\mathrm{CMG}$ at $\mathrm{p}<0.05$.

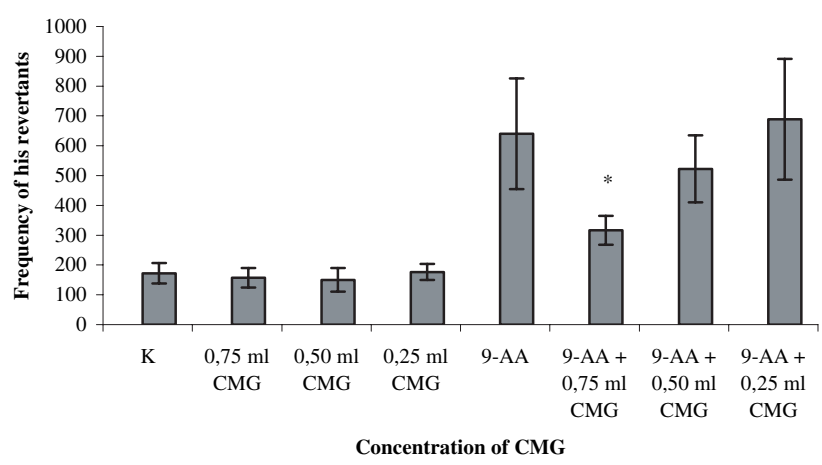

Fig. 3. Antigenotoxic effect of CMG against 9-AA-induced mutagenity in Salmonella typhimurium TA97

* significant difference between 9-AA $(100 \mu \mathrm{g} /$ plate $)$ and $9-\mathrm{AA}+\mathrm{CMG}(0.25-0.75 \mathrm{ml} /$ plate $)$ at $\mathrm{p}<0.05$.

typhimurium TA97 (Fig. 3), but his ${ }^{+}$revertants decreasing was statistically significant only at the highest concentration of CMG.

\section{DISCUSSION}

The conventional treatment of surgery, radiation, and chemotherapy has been the cornerstone of cancer treatment over the past 50 years. Today, the clinical success of these treatments has reached a plateau. There is an urgent need to break through this cure plateau by trying fresh approaches. Acceptance and utilization of BRMs, including $\mathrm{CMG}$, is one of them. As $\beta$-D-glucan isolated from $S$. cerevisiae is water insoluble, has higher molecular weight, and is resistant against alkali-acid treatments, it was processed by carboxymethylation ${ }^{15}$ on purpose to change these properties and facilitate its potential utilization in medicine. 
For in vitro screening of antimutagens/anticarcinogens various prokaryotic and eukaryotic model organism, which enable to monitor different genetic endpoints, have been used ${ }^{23}$. Reduction of the genotoxic effect of MMS applied on recombination-repair-deficient strain of Chlamydomonas reinhardtii by CMG could be either a result of their interaction resulting in the MMS inactivation (CMG acting as desmutagen), or result of stimulation of non-damaged repair mechanism(s) (e.g., excision repair) by $\mathrm{CMG}$ (CMG acting as bioantimutagen). But, antigenotoxicity explanation due to acting in a desmutagenic manner, is more probable. Moreover, its antioxidative capacity based on efficient free-radical scavenging was also revealed by other authors ${ }^{6,7,24}$. In our experiments on yeast performed with ofloxacin, which is known to be inhibitor of DNA gyrase ${ }^{25}$ and producer of reactive oxygen species (ROS) $)^{26-28}$, a decreased number of revertant colonies (Fig. 1) may be based on ability of CMG to prevent the oxidative damage to DNA induced by ROS which play important role in the multistage carcinogenesis and mutagenesis. Thus, $\mathrm{CMG}$ possesses high antioxidative activity as well as expressive antimutagenic/bioprotective effects, exerted through combined application with other biologically active compound (mutagen/carcinogen). CMG as a representative of fungal polysaccharides is of pharmacological importance due to its potential employment in cancer prevention and therapy.

\section{AKNOWLEDGEMENT}

This work was supported by: APVT-20-002604, VEGA No 1/2337/05, 2/4143/04, 2/4056/24.

\section{REFERENCES}

1. DeFlora S, Bennicelli C, Bagnasco M. (1999) Rationale and mechanism of cancer chemoprevention. Recent Results Cancer Res 151, 29-44.

2. Miadoková E, Vlčková V, Dúhová V. (2000) Antimutagenic effect of $\alpha$-lipoic acid on three model test systems. Pharmazie 55, 862-3.

3. Miadoková E, Svidová S, Vlčková V, Kogan G, Rauko P. (2004) The role of microbial polysaccharides in cancer prevention and therapy. J Cancer Integrative Med 2, 173-8.

4. Šandula J, Kogan G, Kačuráková M, Machová E. (1999) Microbial $(1 \rightarrow 3)-\beta$-D-glucans, their preparation, physico-chemical chracterization and immunomodulatory activity. Carbohydr Polym 38, 247-53.

5. Chorvatovičová D, Machová E, Šandula J. (1993) Protective effect of sulfoethylglucan against hexavalent chromium. Mutat Res 302, 207-11.

6. Babincová M., Bačová Z, Machová E, Kogan G. (2002) Antioxidant activity of carboxymethyl glucan: Comparative analysis. J Med Food 5, 79-83.

7. Slameňová D, Lábaj J, Križková L, Šandula J, Bresgen N, Eckl P. (2003) Protective effects of fungal (1-3)-B-D-glucan derivatives against oxidative DNA lesions in V79 hamster lung cells. Cancer Lett 198, 153-6.

8. Medzhitov R., Janeway CA. (2000) Innate immunity. N Engl J Med $343,338-44$

9. Brown GD, Gordon S. (2001) Immune recognition: A new receptor for $\beta$-glucans. Nature 413, 36-37.
10. Kougias P, Wei D, Rice JP, Ensley HE, Kalbfleisch J, Williams DL, Browder IW. (2001) Normal human fibroblasts express pattern recognition receptors for fungal (1-3)- $\beta$-D-glucans. Infect Immun. 69, 3933-8.

11. Lowe EP, Wei D, Rice PJ, Li, C, Kalbfleisch J, Browder IW, Williams DL. )2002) Human vascular endothelial cells express pattern recognition receptors for fungal glucans which stimulate nuclear factor $\kappa \mathrm{B}$ activation and interleukin 8 production. Am Surg 68, 508-16.

12. Rice PJ., Kelley JL, Kogan G, Ensley HE, Kalbfleisch JH, Browder IW, Williams DL. (2002) Human monocyte scavenger receptors are pattern recognition receptors for (1-3)- $\beta$-D-glucans. J Leuk Biol 72, 140-6.

13. Bohn JA, BeMiller JN (1995) ( $1 \rightarrow 3$ )- $\beta$-D-glucans as biological response modifiers: a review of structure-functional activity relationships. Carbohydr Polym 28, 3-14.

14. Kogan G, Šandula J, Korolenko TA, Falameeva OV, Poteryaeva ON, Zhanaeva SYa, Levina OA, Filatova TG, Kaledin VI. (2002) Increased efficiency of Lewis lung carcinoma chemotherapy with a macrophag stimulator-yeast carboxymethyl glucan. Int Immunopharmacol 2, 775-81.

15. Sier CF, Gelderman KA Prins FA Gorter A. (2004) Beta-glucan enhanced killing of renal cell carcinoma micrometastases by monoclonal antibody G250 directed complement activation. Int J Cancer 109, 900-8.

16. Machová E, Kogan G, Alföldi J, Šoltés L Šandula J. (1995) Enzymatic and ultrasonic depolymerization of carboxymethylated $\beta$-1,3-D-glucans derived from Saccharomyces cerevisiae. J Appl Polym Sci 55, 699-704.

17. Zimmermann FK, von Borstel BC, von Halle ES, Parry JM, Siebert D, Zettenberg G, Barale R, Loprieno N. (1984) Testing of chemicals for genetic activity with Saccharomyces cerevisiae: a report of the U.S. Environmental Protection Agency Gene-Tox Program. Mutat Res 133, 199-244.

18. Podstavková S, Vlček D, Miadoková E, Slivková A. (1996) The localization of Chlamydomonas repair genes. Arch Hydrobiol, Suppl 116, Algol Stud 82, 97-102.

19. Miadoková E, Svidová S, Šubjaková I, Kogan G. (2003) Detection of antimutagenic potential of glucomannan in unicellular green alga and bacteria. Biologia 58, 627-31

20. Murín A. (1984) Simultaneous test of phytotoxic and mutagenic effects of polluted waters and herbicidal chemicals. Biologia 39, $15-24$.

21. Kanaya N, Gill BS, Grover I, Murín A, Osiecka R, Sandhu, SS, Anderson HC. (1994) Vicia faba chromosomal aberration assay. Mutat Res 310, 231-47.

22. Maron DM, Ames BN (1983) Revised methods for the Salmonella mutagenicity test. Revised methods for the Salmonella mutagenicity test. Mutat Res 113,173-215.

23. Carere A, Moh GR, Parry JM, Sors AI, Nolan CV: Methods and testing strategies for evaluating the genotoxic properties of chemicals. Official Publication of European Communities 1995, p. $1-8$.

24. Krizkova L, Durackova Z, Sandula J, Slamenova D, Sasinkova V, Sivonova M, Krajcovic J. (2003) Fungal beta-(1-3)-D-glucan derivatives exhibit high antioxidative and antimutagenic activity in vitro. Anticancer Res 23, 2751-6.

25. Hooper DC, Wolfson JS. Mechanism of quinoline action and bacterial killing. In: Hooper DC, Wolfson JS, editors. Quinoline antibacterial agents. American Society for Microbiology. Washington, 1993. p. 53-75.

26. Umezawa N, Arakane K, Ryu A, Mashiko S, Hirobe M, Nagano T. (1997) Participation of reactive oxygen species in phototoxicity induced by quinolone antibacterial agents. Arch Biochem Biophys 342, 275-81.

27. Krizkova L, Durackova Z, Sandula J, Slamenova D, Sasinkova V, Sivonova M, Krajcovic J. (2003) Fungal beta-(1-3)-D-glucan derivatives exhibit high antioxidative and antimutagenic activity in vitro. Anticancer Res 23, 2751-6.

28. Chorvatovičová D, Machová E, Šandula J. (1993) Protective effect of sulfoethylglucan against hexavalent chromium. Mutat Res 302, 207-11. 